\title{
Comparison of strength and durability characteristics of a geopolymer produced from fly ash, ground glass fiber and glass powder
}

\author{
H. Rashidian-Dezfouli, P. R. Rangaraju $\bowtie$
}

Glenn Department of Civil Engineering, Clemson University, (Clemson, SC, USA)

$\triangle$ prangar@clemson.edu

Received 18 April 2016

Accepted 28 November 2016

Available on line 4 October 2017

\begin{abstract}
Strength and durability characteristics of geopolymers produced using three precursors, consisting of fly ash, Ground Glass Fiber (GGF), and glass-powder were studied. Combinations of sodium hydroxide and sodium silicate were used as the activator solutions, and the effect of different sodium and silica content of the activators on the workability and compressive strength of geopolymers was investigated. The parameters used in this study were the mass ratio of Na2O-to-binder (for sodium content), and $\mathrm{SiO} 2$-to-Na2O of the activator (for silica content). Geopolymer mixtures that achieved the highest compressive strength from each precursor were assessed for their resistance to alkali-silica reaction and compared against the performance of portland cement mixtures. Test results revealed that GGF and fly ash-based geopolymers performed better than glass-powder-based geopolymer mixtures. The resistance of GGF-based and fly ash-based geopolymers to alkali-silica reaction was superior to that of portland cement mixtures, while glass-powder-based geopolymer showed inferior performance.
\end{abstract}

KEYWORDS: Geopolymers; Alkali-Silica Reaction; Ground Glass Fiber; Fly ash; Glass-Powder

Citation/Citar como: Rashidian-Dezfouli, H.; Rangaraju, P.R. (2017) Comparison of strength and durability characteristics of a geopolymer produced from fly ash, ground glass fiber and glass powder. Mater. Construcc. 67 [328], e136 https://doi.org/10.3989/mc.2017.05416

RESUMEN: Comparación de Características de Resistencia y Durabilidad de un Geopolímero obtenido a partir de ceniza Volante, Fibra de Vidrio Esmerilado y Polvo de Vidrio. Se estudiaron las características de resistencia y durabilidad de geopolímeros producidos utilizando tres precursores, formados por cenizas volantes, Fibra de Vidrio Esmerilado (FVE) y vidrio en polvo. Se utilizaron combinaciones de soluciones de hidróxido de sodio y silicato de sodio como activadores, y se investigó el efecto del diferente contenido de sodio y sílice de los activadores en la trabajabilidad y resistencia a la compresión de los geopolímeros. Los parámetros utilizados en este estudio fueron la relación de masa de $\mathrm{Na}_{2} \mathrm{O}$-a-aglutinante (para el contenido de sodio), y $\mathrm{SiO}_{2}-\mathrm{a}-\mathrm{Na}_{2} \mathrm{O}$ del activador (para el contenido de sílice). Las mezclas de geopolímeros obtenidas a partir de cada precursor que alcanzaron la más alta resistencia a la compresión fueron evaluadas por su resistencia a la reacción álcali-sílice y comparadas con el rendimiento de las mezclas de cemento portland. Los resultados de las pruebas revelaron que la FVE y los geopolímeros a base de ceniza volante se comportaron mejor que las mezclas de geopolímeros a base de vidrio en polvo. La resistencia de los geopolímeros a base de ceniza volante y FVE a la reacción álcali-sílice fue superior que la de las mezclas de cemento portland, mientras que los geopolímeros a base de vidrio en polvo mostraron un rendimiento inferior.

PALABRAS CLAVE: Geopolímeros; Reacción alkali-sílice; Fibra de vidrio esmerilado; Ceniza volante; Polvo de vidrio

ORCID ID: H. Rashidian-Dezfouli (http://orcid.org/0000-0002-6606-8716); P.R. Rangaraju (http://orcid. org/0000-0003-4285-1252)

Copyright: (C) 2017 CSIC. This is an open-access article distributed under the terms of the Creative Commons Attribution License (CC BY) Spain 3.0. 


\section{INTRODUCTION}

Each year, a large amount of glass fiber is produced around the world for use in various applications. However, this process generates hundreds of thousands of tons of waste glass fiber. It has been reported that, in the U.S., around 250,000 to 500,000 tons of waste glass fiber end-up in landfills each year (1). This waste material is rich in silica, alumina, and calcium and if ground to a fine powder, might potentially be used as supplementary cementitious material (SCM) or as a precursor for production of geopolymer. Chen et al. (2) studied the utilization of waste E-glass (the most commonly used type of fiber glass) as cement replacement material. In addition, a number of studies were also conducted on the utilization of vitreous calcium aluminosilicate (which is a commercially produced pozzolan made from by-products of fiber glass) as cement replacement material $(3,4)$ or as a precursor for geopolymer production $(5,6)$.

So far, a large number of waste or industrial byproduct materials have been studied as precursors to produce geopolymer concrete. Among them, flyash, slag, and meta-kaolin and their combinations are the most widely used materials (7-14). In addition, other materials like kaolinite and albite (15), waste paper sludge ash (16), palm oil fuel Ash (17), spent fluid catalytic cracking catalyst (18), waste glass-powder (19), blends of clay and fly ash (20), a combination of fly ash and anhydrous borax (21), and combination of natural pozzolan and slag (22) were studied by other authors. Thus far, no studies have been conducted on the use of GGF in geopolymer systems.

Earlier studies, performed mostly on fly-ash or metakaolin based geopolymer mixtures, have revealed some of the important parameters that affect the mechanical properties of final geopolymer products. It has been reported that parameters, such as type and concentration of the alkali solution (23, 24), ratio of $\mathrm{SiO}_{2} / \mathrm{Na}_{2} \mathrm{O}$ in the alkali activator solution $(24,26)$, availability of calcium compounds $(10,27,28)$, extent of dissolution of precursors in an alkali media $(15,29)$, and the molar ratio of $\mathrm{Si}: \mathrm{Al}$ in the final product (30-32) are parameters that can affect mechanical properties of final geopolymer products.

Several studies have also been conducted on durability aspects of geopolymers. Considering the high amount of alkali present in geopolymers, the potential for Alkali Silica Reaction (ASR) in aggregates used in geopolymers has always been a big concern. Susceptibility of fly ash-based geopolymer mixtures to ASR have been studied in several works $(33-37)$. Results of these studies showed a better ASR-resistance of geopolymer mixtures in comparison to a portland cement based mixture. The better performance of geopolymer mixtures in reduction of ASR-related expansion has been attributed to: lower calcium content of the geopolymer paste in comparison to portland cement based mixtures (33, $35,36)$, further geopolymerisation of geopolymer mixtures in the ASR-test condition $(33,34,36)$, and the higher amount of total porosity (with smaller pore diameter) of the geopolymer paste in comparison to portland cement paste (37).

In this study, the activation process for three different materials, i.e. class F fly ash, Ground Glass Fiber (GGF), and ground bottle glass in a powder form, was investigated. The activators used in this study were combinations of $\mathrm{NaOH}$ and $\mathrm{Na}_{2} \mathrm{SiO}_{3}$ solutions in various concentrations and proportions of activators. In addition, accelerated curing for 24 $\mathrm{h}$ at $60^{\circ} \mathrm{C}$ was used in this study for all the mixtures evaluated.

The first objective of this study was to investigate the effect of using different dosages of activator as measured by the mass ratio of $\mathrm{Na}_{2} \mathrm{O}$-to-binder and the ratio of sodium hydroxide and sodium silicate in the activator solution as measured by $\mathrm{Si}_{2} \mathrm{O} / \mathrm{Na}_{2} \mathrm{O}$ mass ratio on workability and compressive strength of the geopolymer concretes. The second objective of this study was to evaluate the performance of mixtures that resulted in the highest compressive strength under the first objective to determine their resistance to ASR.

\section{EXPERIMENTAL PROCEDURE}

\subsection{Materials}

The materials used in this study were:

1. Alumino-siliceous precursors for geopolymers including GGF, class F fly ash and glass powder with average particle size of 4,28 and 17 microns, respectively.

2. For conducting comparative studies with for portland cement mixtures an ASTM C150 (38) Type I cement was selected.

3. Locally available siliceous river sand with ovendry specific gravity of 2.67 and absorption of $0.30 \%$ was used as a fine aggregate in preparing the mortar mixtures. Reactive rhyolitic gravel from Las Placitas gravel pit was used in studies related to ASR mitigation.

4. The alkali activators used in this study were $40 \%$ sodium-silicate solution $\left(\mathrm{SiO}_{2} / \mathrm{Na}_{2} \mathrm{O}=3\right.$, weight ratio) and anhydrous $\mathrm{NaOH}$ pellets.

The GGF used in this study is a fine white powder produced by grinding waste fiber glass. The fly ash in this study is a Class F fly ash obtained from a local source. The glass powder was obtained from finely ground recycled glass bottles. Basic physical properties and chemical composition of the precursor can be seen in Table 1 and Table 2, respectively. 
TABLE 1. Basic properties of the precursors

\begin{tabular}{lcccc}
\hline Material & Specific Gravity & Amount Passing \#325 Sieve (\%) & Loss On Ignition & Blaine's fineness $\left(\mathbf{c m}^{2} / \mathbf{g}\right)$ \\
\hline GGF & 2.6 & $96 \%$ & $1.0 \%$ & 10200 \\
Fly ash & 2.25 & $76 \%$ & $2.3 \%$ & 6040 \\
Glass Powder & 2.4 & $83 \%$ & $1.5 \%$ & 5920 \\
Cement & 3.15 & $98 \%$ & $2.6 \%$ & 4720 \\
\hline
\end{tabular}

TABLE 2. Chemical composition of the precursors

\begin{tabular}{lccccccc}
\hline & $\mathbf{S i O}_{2}$ & $\mathrm{Al}_{2} \mathbf{O}_{3}$ & $\mathbf{F e}_{2} \mathbf{O}_{3}$ & $\mathbf{C a O}$ & $\mathbf{M g O}$ & $\mathbf{N a}_{2} \mathbf{O}$ & $\mathbf{K}_{2} \mathbf{O}$ \\
\hline GGF (\%) & 47.72 & 10.36 & 0.34 & 19.62 & 2.27 & 0.67 & 0.1 \\
Fly Ash (\%) & 50.7 & 25.1 & 12.5 & 3.3 & 1.1 & 0.51 & 2.27 \\
Glass Powder & 69.6 & 2.2 & 0.9 & 11.6 & 0.4 & 12.03 & 0.4 \\
Cement (\%) & 19.93 & 4.77 & 3.13 & 62.27 & 2.7 & 0.06 & 0.48 \\
\hline
\end{tabular}

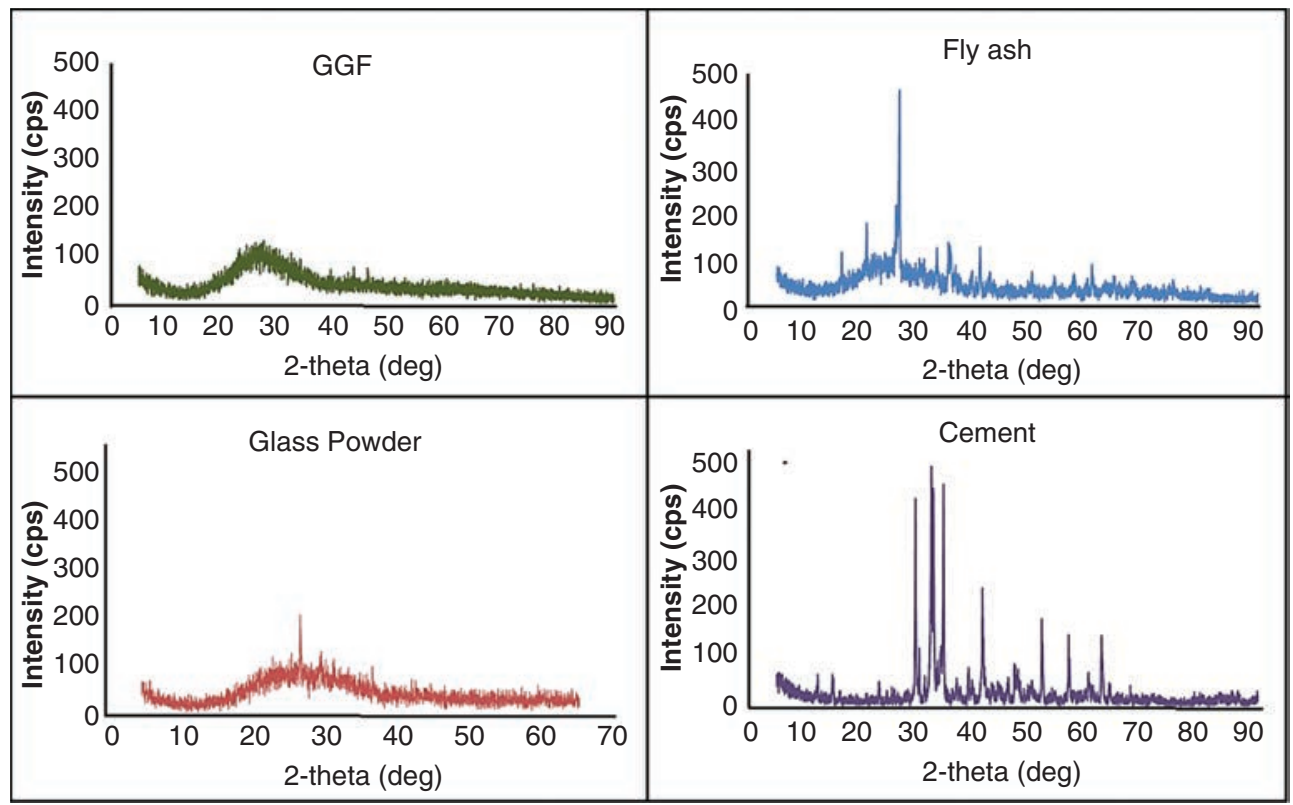

FIGURE 1. XRD pattern of the cementitious materials: GGF (top left), Fly ash (top right), Glass-powder (bottom left) and Cement (bottom right).

In addition, the XRD pattern of the cementitious materials that were used in this study are presented in Figure 1.

\subsection{Mixture Proportions}

Effect of the relative proportion of the two activators (sodium silicate and sodium hydroxide) on the fresh and hardened properties of geopolymers was studied by changing two parameters. Firstly, the mass ratio of total $\mathrm{Na}_{2} \mathrm{O}$-to-binder at three different levels $-5 \%, 7.5 \%$ and $10 \%$ - was used. Secondly, the mass ratio of $\mathrm{SiO}_{2} / \mathrm{Na}_{2} \mathrm{O}$ at three levels $-0,0.50$ and 1.00 - was used. In all the mixtures, the sand content was selected to fill $55 \%$ of the total volume, and the water-to-binder ratio was maintained between 0.30 and 0.35 . This range was chosen to get the highest possible strength while the mixtures were workable without the need for any water reducers. The details of the test plan are presented in Table 3.

\subsection{Flow test and compressive strength}

The water-to-binder ratio employed in geopolymer mixtures is generally between $0.20-0.40$ which is lower than the normal water-to-binder ratios used in conventional portland cement concrete and mortar. To examine the effect of different precursors and the chemical ratios (alkali-to-binder ratio and $\left.\mathrm{SiO}_{2} / \mathrm{Na}_{2} \mathrm{O}\right)$ on the flowability of the geopolymer 
TABLE 3. Mixture proportions

\begin{tabular}{|c|c|c|c|c|c|c|c|c|}
\hline & Mix ID & GGF-0-10 & GGF-0.5-5 & GGF-0.5-7.5 & GGF-0.5-10 & GGF-1-5 & GGF-1-7.5 & GGF-1-10 \\
\hline \multirow{5}{*}{ GGF } & $\mathrm{Na}_{2} \mathrm{O} / \mathrm{Binder}(\%)$ & 10 & 5 & 7.5 & 10 & 5 & 7.5 & 10 \\
\hline & $\mathrm{SiO}_{2} / \mathrm{Na}_{2} \mathrm{O}$ & 0 & 0.5 & 0.5 & 0.5 & 1 & 1 & 1 \\
\hline & W/Binder & 0.33 & 0.33 & 0.33 & 0.33 & 0.33 & 0.33 & 0.33 \\
\hline & Mix ID & F-0-10 & F-0.5-5 & F-0.5-7.5 & F-0.5-10 & F-1-5 & F-1-7.5 & F-1-10 \\
\hline & $\mathrm{Na}_{2} \mathrm{O} /$ Binder $(\%)$ & 10 & 5 & 7.5 & 10 & 5 & 7.5 & 10 \\
\hline \multirow[t]{4}{*}{ Fly-ash } & $\mathrm{SiO}_{2} / \mathrm{Na}_{2} \mathrm{O}$ & 0 & 0.5 & 0.5 & 0.5 & 1 & 1 & 1 \\
\hline & W/Binder & 0.3 & 0.3 & 0.3 & 0.3 & 0.3 & 0.3 & 0.3 \\
\hline & Mix ID & GP-0-3 & GP-0.5-5 & GP-0.5-7.5 & GP-0.5-10 & GP-1-5 & GP-1-7.5 & GP-1-10 \\
\hline & W/Binder & 10 & 10 & 7.5 & 5 & 10 & 7.5 & 5 \\
\hline \multirow[t]{2}{*}{ Glass-Powder } & $\mathrm{SiO}_{2} / \mathrm{Na}_{2} \mathrm{O}$ & 0 & 0.5 & 0.5 & 0.5 & 1 & 1 & 1 \\
\hline & $\mathrm{Na}_{2} \mathrm{O} /$ Binder $(\%)$ & 0.35 & 0.35 & 0.35 & 0.35 & 0.35 & 0.35 & 0.35 \\
\hline
\end{tabular}

mixtures, flow test (ASTM C1437) (39) was done on each of the blends. To evaluate the compressive strength, $50 \times 50 \times 50 \mathrm{~mm}$ mortar cubes were cast. The mixing procedure began with dissolving required amount of $\mathrm{NaOH}$ in water. The sodium-silicate solution was then added, and mixing process continued until all the $\mathrm{NaOH}$ pellets were completely dissolved. Immediately after the dissolution of all $\mathrm{NaOH}$ pellets, the precursor was added to the solution and mixed for 1 additional minute. Lastly, the fine aggregate was introduced into the mixer and mixing process continued until uniform mix was achieved. The material was then placed in the cube molds and transferred to a $60^{\circ} \mathrm{C}$ chamber for a 24 -hour period of heat curing. After 24 hours, cubes were removed from molds and placed inside an environmental chamber, maintained at $23^{\circ} \mathrm{C}$ temperature and $50 \%$ relative humidity, until the time of testing. The compressive strength was measured at 3, 7 and 28 days following the ASTM C109 (40) procedure. Additional mortar prisms were also cast to investigate the microstructure using scanning electron microscopy (SEM).

\subsection{Dissolution of paste in $\mathrm{HCl}$ acid solution}

In this study, $\mathrm{HCl}$ solution is used to find the amount of unreacted GGF particles of geopolymer mixtures. This solution is known to dissolve the geopolymer structure and leave the unreacted precursor particles behind $(41,42)$. In this study, following Palomo et al (42), dissolution of selected paste were studied in a 1:20 $\mathrm{HCl}$ solution (i.e. $50 \mathrm{ml}$ of $1 \mathrm{~N} \mathrm{HCl}$ solution in $1000 \mathrm{ml}$ water). Geopolymer paste was crushed to a fine powder and the amount passing sieve \#100 and retaining \#200 sieved was selected for the test. To perform the test, 2 grams of the paste powder was introduced into $500 \mathrm{ml}$ of $\mathrm{HCl}$ solution and the solution was mixed for $3 \mathrm{~h}$ using a magnetic stirrer. The solution then was filtered using $1.5 \mu \mathrm{m}$ filter paper. The residue was dried at $110^{\circ} \mathrm{C}$ for 24 hours, then weighed and recorded.

\subsection{Extent of dissolution}

Solubility of raw material in high alkali media was determined by mixing 5 grams of each precursor in $100 \mathrm{ml}$ of $5 \mathrm{~N} \mathrm{NaOH}$ solution. Solutions were mixed for $2 \mathrm{hr}$. at ambient temperature using a magnetic stirrer. The solution was filtered using micro fiber filters and then diluted to 1:100 using deionized water. Inductively coupled plasma (ICP) test was performed to analyze the filtered solution. The concentration of soluble $\mathrm{Si}, \mathrm{Al}, \mathrm{Ca}$ and $\mathrm{Fe}$ was measured for the diluted solution. The results were then back-calculated for the original concentration of the dissolved elements in the $5 \mathrm{~N} \mathrm{NaOH}$ solution.

\subsection{Alkali-silica reactivity of aggregates in geopolymers}

Accelerated mortar bar test using ASTM C1260 (43) procedure was followed to study the ASR behavior in geopolymer mortar specimens. A known alkali-silica-reactive aggregate, Las Placitas gravel from New-Mexico, was crushed to meet the gradation requirements of ASTM C1260 and was used as the fine aggregate in all the mixtures. Following the ASTM C1260 procedure, the binder-to-aggregate ratio was selected such that for 1 part by weight of dry source-materials (i.e. GGF, fly ash or glass-powder), 2.25 parts by weight for the crushed aggregate by mass were used.

In this study, ASTM C1260 test was used, realizing that even though the test is being run on geopolymer mortars rather than portland cement mortars, as no suitable test method is presently available to evaluate ASR behavior of aggregates in geopolymers. The binder portion of the geopolymer test specimens followed the proportions given in Table 3. Same mixing and curing procedure as described in section 2.3 were followed in preparing the mortar prisms for ASR study. The specimens were removed after $24 \mathrm{~h}$ in $60^{\circ} \mathrm{C}$ environment and submerged in water at $80^{\circ} \mathrm{C}$ for 
addition $24 \mathrm{~h}$. Finally, the mortar bars were immersed in $1 \mathrm{~N} \mathrm{NaOH}$ solution and kept in $80^{\circ} \mathrm{C}$ oven for the remaining duration of the test. The length change in the mortar bars was monitored up to 28 days after submerging in the solution. The ASR performance of geopolymer samples was compared with that of portland cement mortar samples with a water/cement ratio of 0.35 and same content of aggregate in the mixture as in the case of geopolymer samples. It should be noted that portland cement mixture had gone through identical curing procedure, $24 \mathrm{~h}$ in $60^{\circ} \mathrm{C}$ followed by ambient curing $\left(23^{\circ} \mathrm{C}\right.$ and $\left.50 \% \mathrm{RH}\right)$, as geopolymer samples for the purposes of this investigation.

\section{RESULTS AND DISCUSSION}

\subsection{Flow test}

Figure 2 shows the flow results of geopolymer samples. As it can be seen, GGF-based geopolymer mortar showed the highest flow while glass powderbased geopolymer mortar had the lowest flow. The workability of fresh geopolymer mixtures has been reported to vary with the change in the alkali content of the solution as well as its $\mathrm{SiO}_{2} / \mathrm{Na}_{2} \mathrm{O}$ ratio (44-46). According to these studies, increase in Na concentration and $\mathrm{SiO}_{2} / \mathrm{Na}_{2} \mathrm{O}$ ratio will reduce the workability of the mixture. In the present study, however, increase in the alkali content of the activator solution from 5 to $10 \%\left(\mathrm{Na}_{2} \mathrm{O}\right.$-to-binder mass ratio) did not seem to have a considerable effect on the flow results of fly ash and GGF-based mixtures but caused improvement in the workability of glass-powder-based mixtures. On the other hand, increase in $\mathrm{SiO}_{2} / \mathrm{Na}_{2} \mathrm{O}$ ratio showed a clear improvement in the workability of the mixtures, which is in agreement with the earlier mentioned studies.
The main mechanism by which increase in $\mathrm{SiO}_{2} /$ $\mathrm{Na}_{2} \mathrm{O}$ ratio improved the workability is thought to be related to the mixing procedure that was followed in this study. As presented in section 2.3, the first step of the mixing procedure was to dissolve $\mathrm{NaOH}$ pellets in the required amount of water, which is followed by the addition of the precursors. The dissolution of $\mathrm{NaOH}$ pellets is an exothermic reaction and increases the temperature of the mixture which lowers the workability. However, addition of soluble $\mathrm{Si}$ was done by using pre-mixed sodium silicate (ambient temperature), and therefore, cooling the mixture. The lower temperature of the mixture with higher $\mathrm{SiO}_{2} / \mathrm{Na}_{2} \mathrm{O}$ ratio is thought to be the main reason for the better workability of these mixtures. A same observation has been also reported by (47), in which $\mathrm{NaOH}$ solution was not allowed to cool down.

It was also observed that GGF mixtures had the highest viscosity in the flow test (based on visual observation of the stickiness of the mixtures). The fly-ash based material, however, showed the lowest viscosity and was easier to work with. For mixtures with very low workability (Glass-powder based samples), a High Range Water Reducer (HRWR, MasterGlenium ${ }^{\circledR} 7500$ ) was used to ensure an adequate flow for proper compaction of test specimens for other tests. The amount of HRWR was measured to be $1.5 \%$ of the weight of the glass-powder and no HRWR was needed for the GGF and fly ash-based geopolymer samples.

\subsection{Compressive strength}

Compressive strength of geopolymer samples are presented in Table 4 and Figure 3. As it can be seen for all the precursors, compressive strength increases

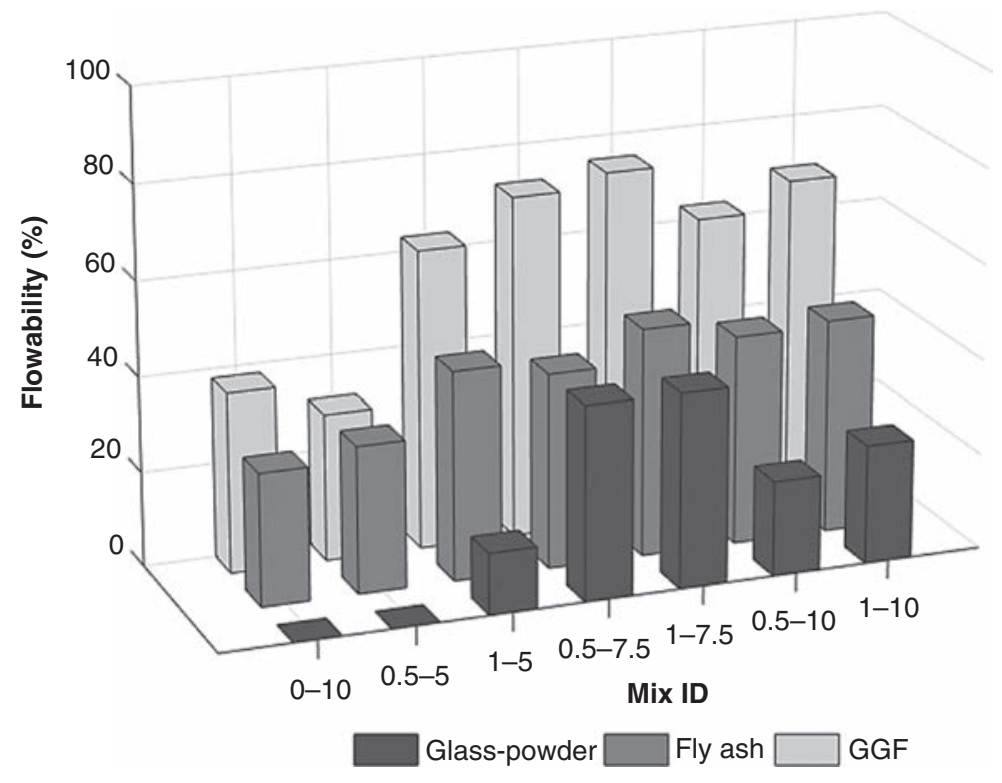

Figure 2. Flow results of geopolymer mortars. 
TABLE 4. Compressive strength of geopolymer cubes (MPa)

\begin{tabular}{|c|c|c|c|c|c|c|c|c|c|c|}
\hline \multirow{2}{*}{\multicolumn{2}{|c|}{$\begin{array}{c}\text { Precursor } \\
\mathrm{Na}_{2} \mathrm{O} /(\text { Source-material), } \%\end{array}$}} & \multicolumn{3}{|c|}{ GGF } & \multicolumn{3}{|c|}{ Fly ash } & \multicolumn{3}{|c|}{ Glass-Powder } \\
\hline & & 5 & 7.5 & 10 & 5 & 7.5 & 10 & 5 & 7.5 & 10 \\
\hline Age & $\mathrm{SiO}_{2} / \mathrm{Na}_{2} \mathrm{O}$ & \multicolumn{9}{|c|}{ Compressive Strength, MPa } \\
\hline \multirow{4}{*}{3 days } & 0 & - & - & 79 & - & - & 14 & - & - & 7 \\
\hline & 0.5 & 27 & 53 & 67 & NA & 16 & 35 & 7 & 22 & 19 \\
\hline & 1 & 25 & 58 & 69 & 16 & 43 & 58 & 21 & 30 & 37 \\
\hline & 0 & - & - & 78 & - & - & 20 & - & - & 11 \\
\hline \multirow[t]{3}{*}{7 days } & 0.5 & 28 & 54 & 75 & NA & 17 & 36 & 9 & 32 & 22 \\
\hline & 1 & 27 & 53 & 72 & 21 & 44 & 60 & 29 & 40 & 40 \\
\hline & 0 & - & - & 82 & - & - & 25 & - & - & 14 \\
\hline \multirow[t]{2}{*}{28 days } & 0.5 & 29 & 55 & 72 & NA & 22 & 46 & 16 & 28 & 33 \\
\hline & 1 & 28 & 56 & 67 & 24 & 45 & 59 & 35 & 36 & 43 \\
\hline
\end{tabular}


- 日- Na Content $=5 \%$

$\rightarrow$ Na Content $=7.5 \%$ - Na Content $=10 \%$

FIgURE 3. Change in the compressive strength of geopolymers mortar at 28 days due to the change in $\mathrm{Na}$ content and $\mathrm{SiO}_{2} / \mathrm{Na}_{2} \mathrm{O}$.

with an increase in the $\mathrm{Na}$ content of the mixture. At 28 days, the compressive strength of GGF samples having $\mathrm{SiO}_{2} / \mathrm{Na}_{2} \mathrm{O}=0.5(\mathrm{GGF}-0.5)$ and $\mathrm{SiO}_{2} /$ $\mathrm{Na}_{2} \mathrm{O}=1.0(\mathrm{GGF}-1)$ showed an increase from 29 to $72 \mathrm{MPa}$ and 28 to $67 \mathrm{MPa}$ respectively, when the $\mathrm{Na}$ content of the mixture was increased from 5\% to $10 \%$. Similarly, the compressive strength of geopolymer samples containing fly ash having $\mathrm{SiO}_{2} / \mathrm{Na}_{2} \mathrm{O}$ $=0.5(\mathrm{~F}-0.5)$ and $\mathrm{SiO}_{2} / \mathrm{Na}_{2} \mathrm{O}=1.0(\mathrm{~F}-1)$ showed an increase in compressive strength from less than $5 \mathrm{MPa}$ to $46 \mathrm{MPa}$ and 24 to $59 \mathrm{MPa}$, respectively, when the $\mathrm{Na}$ content of the mixture was increased from $5 \%$ to $10 \%$.

Except for the glass-powder geopolymer mixture with $\mathrm{SiO}_{2} / \mathrm{Na}_{2} \mathrm{O}=0.5$ and $\mathrm{Na}_{2} \mathrm{O}$ content of 10\% (GP-0.5-10 sample), an almost similar trend as observed with GGF and fly ash can be seen in other geopolymers prepared with glass-powder. However, the difference in the compressive strength between glass powder-based geopolymer mixtures containing $7.5 \%$ and $10 \% \mathrm{Na}_{2} \mathrm{O}$ content were smaller than observed with geopolymers prepared with other precursors. This could be attributed to the large amount of alkalis that are already present in glasspowder. It is assumed that glass particles release $\mathrm{Na}^{+}$into the surrounding media and act as an internal source of alkalis, which reduces the effect of the external source of alkalis.

The effect of soluble Si content in the activator solution seems to be very important in fly ash and glass-powder-based geopolymer samples, while it is less significant in the case of GGF. In 28 day-old fly ash samples with $10 \% \mathrm{Na}_{2} \mathrm{O}$ content, for $\mathrm{SiO}_{2} / \mathrm{Na}_{2} \mathrm{O}$ ratios of $0,0.5$, and 1 , the compressive strength values were 25, 46, and $59 \mathrm{MPa}$ respectively. In the case of glass-powder samples, for $\mathrm{SiO}_{2} / \mathrm{Na}_{2} \mathrm{O}$ ratios of 0 , 0.5 , and 1 , the compressive strength values were 14 , 33 , and $43 \mathrm{MPa}$ respectively. However, as can be seen, GGF samples do not follow this trend, and an increase in the $\mathrm{SiO}_{2} / \mathrm{Na}_{2} \mathrm{O}$ ratio from 0 to 1 causes reduction in compressive strength from $82 \mathrm{MPa}$ to $67 \mathrm{MPa}$. The highest strength observed was in the case of GGF-010 , which has no Si in the activator solution.

Addition of soluble Si to mixtures also affects the rate of strength gain. Samples with larger Si content showed high early-age strengths (i.e. 3 days) and no 
significant improvement in the strength was observed at later ages, indicating much of the strength gain was achieved within the first 3 days. It was also seen that GGF samples had the highest compressive strength for all levels of activator dosage in comparison to fly ash and glass-powder-based geopolymer samples.

The higher compressive strength of GGF-0-10 specimens (with no added soluble silica) in comparison to GGF-0.5-10 and GGF-1-10 specimens (with silica-to-binder ratio of 5 and $10 \%$ ) can be related to the lower level of unreacted GGF particles in GGF0-10 specimens. Higher amount of available soluble $\mathrm{Si}$ (from sodium silicate solution) is thought to reduce the solubility of the GGF particles in these mixtures and cause reduction in the compressive strength. To evaluate the amount of unreacted GGF particles in GGF-0-10 and GGF-1-10, two grams of paste from each of the mixtures were dissolved in an $\mathrm{HCl}$ solution using the method described in section 2.4. Results of this test are presented in Table 5. As it can be seen a higher amount of residue (unreacted GGF particles) was measured in GGF-1-10 paste specimens. Therefore, the better performance of GGF-0-10 specimens can be related to the higher level of GGF particles in this mixture.

Presence of $\mathrm{Ca}$ in geopolymer systems is known to accelerate the hardening process (27). It is thought that $\mathrm{Ca}^{+2}$ ions balance the negative charge associated with $\mathrm{Al}(\mathrm{OH})_{4}^{-}$and leave more $\mathrm{Na}$ in the system,

TABLE 5. Residue percent of GGF-0-10 and GGF-1-10 paste after dissolution in $\mathrm{HCl}$ solution

\begin{tabular}{lc}
\hline Mix ID & Residue (weight \%) \\
\hline GGF-0-10 & 47 \\
GGF-1-10 & 55 \\
\hline
\end{tabular}

which further accelerates the geopolymerisation. Higher strength of GGF samples even with low $\mathrm{Na}$ content might be explained by the presence of $\mathrm{Ca}$ in the GGF matrix. Although other mechanisms such as the formation of calcium-silicate-hydrate and calcium-aluminum-silicate-hydrate, have been proposed by others (48), however, the study of the mechanisms by which calcium improves the compressive strength of the GGF geopolymer was not investigated in this study, which needs to be investigated in the future.

The solubility test was performed on all the precursors to measure the extent of dissolution of $\mathrm{Si}$, $\mathrm{Al}$ and $\mathrm{Ca}$ in a high alkali solution of $5 \mathrm{M} \mathrm{NaOH}$ solution (Table 5). As shown in this table, GGF releases a higher amount of $\mathrm{Si}$ and $\mathrm{Ca}$ in comparison to fly-ash, while they both produce a higher amount of $\mathrm{Al}$ in comparison to glass-powder. While the XRF result showed higher Al content in fly ash, the amount of dissolved Al for GGF was in the same range as the fly ash sample. Therefore, it could be concluded that, in comparison to GGF, Al in fly ash is bound more strongly, which could be attributed to the presence of mullite in fly ash.

The lower solubility of Si and Al in fly ash can be related to the presence of quartz and mullite crystals. Mullite and quartz are known to be stable and do not easily dissolve in a high alkali solution (49, 50). As a result, compressive strength of the fly ashbased geopolymer can be affected by the presence of crystals of quartz and mullite in the fly ash particles. According to Temuujin and Van Riessen (51) presence of mullite in the fly ash lowers the reactivity of fly ash and decreases the level of geopolymerisation. In this study, the XRD test was conducted on virgin fly ash particles and F-1-10 geopolymer paste. The results showed that mullite and quartz peaks in fly ash specimens remain intact even after the reaction

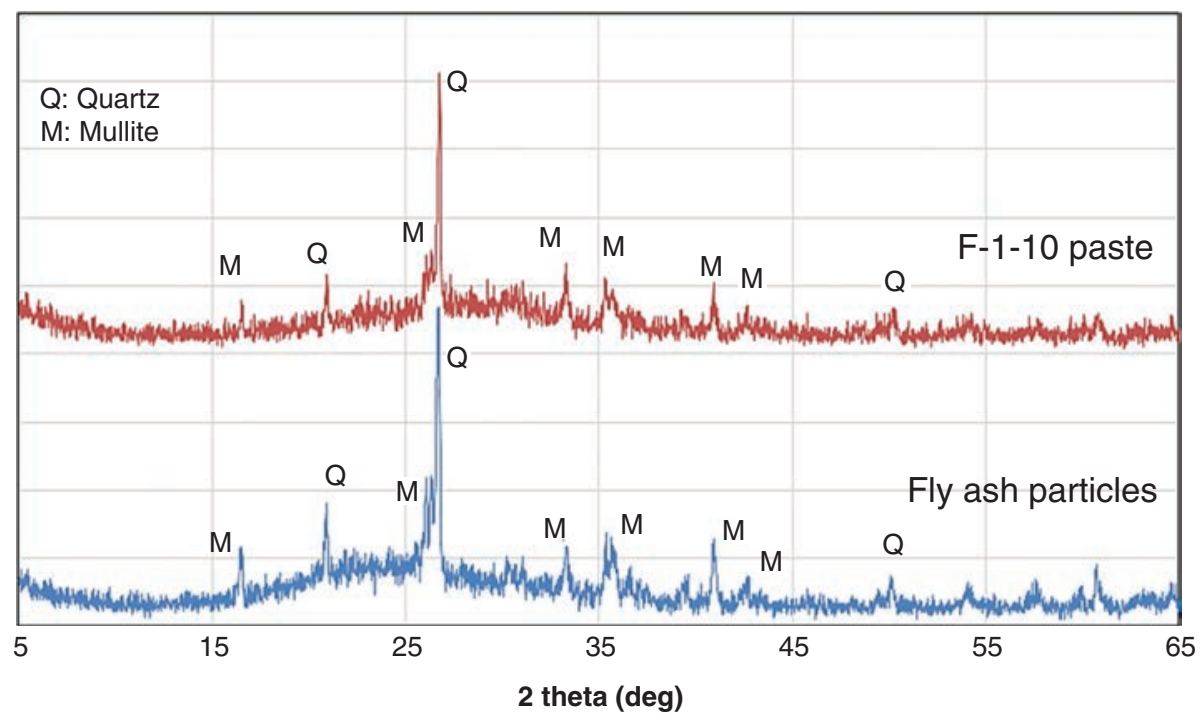

FIGURE 4. XRD pattern of fly ash particles and F-1-10 paste. 
process (Figure 4), which can be attributed to the lower degree of geopolymerisation of the fly ash based geopolymer.

Glass-powder samples, however, released an even lower amount of $\mathrm{Al}$ in the solution compared to GGF and fly ash. Glasser and Harvey as well as $\mathrm{Xu}$ et al. indicated that $\mathrm{Al}$ compounds do not readily combine with the small highly charged silicate monomers, instead they form silica-alumina complexes with long-chain silicate oligomers $(29,52)$. In such cases when the Si/Al ratio is so high (higher than 15), the geopolymeric material shows more polymeric characterization (53). It should also be noted that presence of $\mathrm{Al}$ in the geopolymer structure can bind the alkali as they are required to balance the negative charge associated with $\mathrm{Al}(\mathrm{OH})_{4}^{-}$. As a result, the low Al content leaves higher free alkali in the system, which may end up in ASR gel in the paste matrix of glass-powder-based geopolymers.

Samples with the highest compressive strength from each precursor were selected to investigate the microstructure using back-scatter SEM. These samples were GGF-0-10, F-1-10, and GP-1-10, which showed 82, 59, and $43 \mathrm{MPa}$ at their 28 days. Pictures showing the general appearances of each sample are presented in Figure 5. As presented in this picture, severe damages in the form of voids and cracks can be seen in GP-1-10 sample. The cracks and voids could be related to the high shrinkage tendency of glass-powder geopolymer cured at elevated temperature and also, presence of high dosage of alkali which resulted in formation of ASR gel. Although the shrinkage tests are on-going and are not presented or discussed in detail in this paper, the 28-day results of the drying shrinkage test of geopolymer mortars showed the high shrinkage of glasspowder-based samples. Results of the 28 days old GP-1-10 mortar sample was measured to be 2700 micro-strain, while GGF-0-10 and F-1-10 sample showed 620 and 700 micro-strain respectively. This shows the higher shrinkage tendency of the GP-1-10 mixture.

Figure 6 presents the microstructure of GGF-010 and F-1-10 paste. As it can be seen in this picture, unreacted GGF particles are observed as discrete particles in the paste, while reaction products connect them together. Considering the rigid nature of these particles, they act as an internal reinforcement
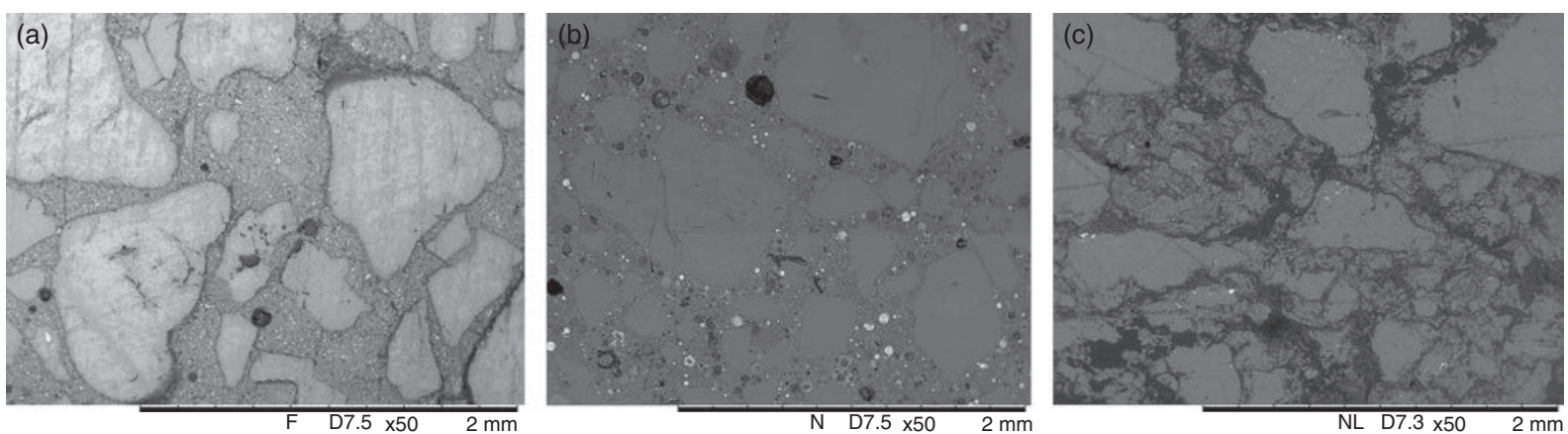

FIGURE 5. General appearance of GGF-0-10 (a), F-1-10 (b) and GP-1-10 (c).
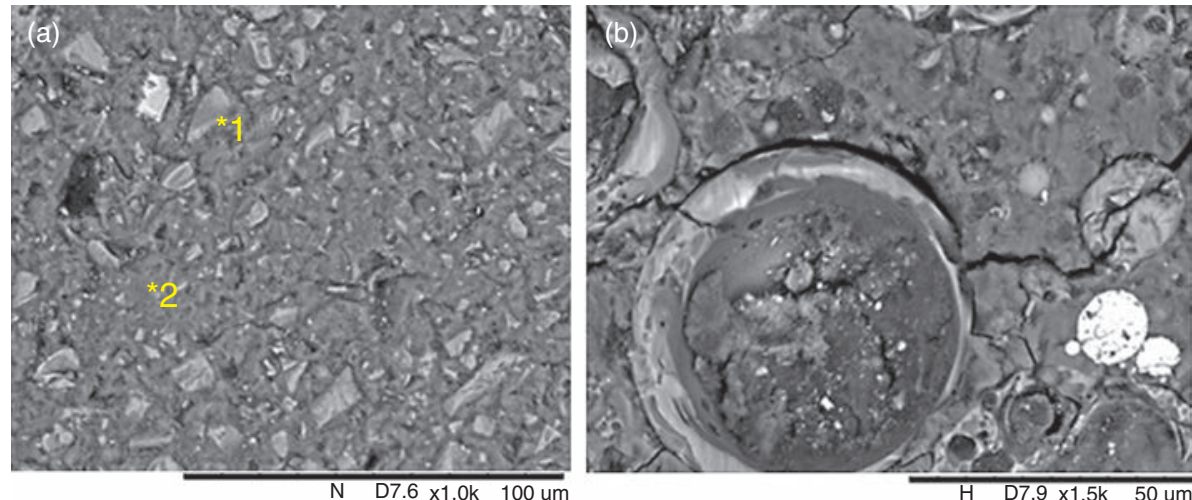

Weight Percentage of Elements

\begin{tabular}{lrrrrccc}
\hline & $\mathrm{Na}$ & $\mathrm{Mg}$ & $\mathrm{Al}$ & $\mathrm{Si}$ & $\mathrm{K}$ & $\mathrm{Ca}$ & $\mathrm{Fe}$ \\
\hline Spectrum 1 & 5.61 & 2.98 & 11.41 & 52.75 & 0.13 & 26.67 & 0.46 \\
Spectrum 2 & 14.98 & 2.14 & 9.96 & 47.38 & 0.89 & 24.99 & 0.47 \\
\hline
\end{tabular}

Figure 6. Microstructure of a) GGF-0-10 and b) F-1-10 Paste. 
in the paste matrix which leads to higher compressive strength of the GGF samples. The EDX results showed a higher amount of $\mathrm{Na}$ in the reaction products, while the other compounds had an almost same proportion in both unreacted particles and surrounding products. As presented in this picture, unreacted particles of fly ash were observed in F-1-10 samples. Nevertheless, the structure of fly ash grains did not appear to be as rigid as GGF grains since micro cracks observed to pass through the un-reacted materials. In the case of glass-powder geopolymer however, an ASR-like gel in the matrix caused cracks in the weak gel as presented in Figure 7.

\subsection{Alkali-silica reaction}

Expansion results of the ASR test are presented in Figure 8. As it can be seen in this graph, GP-1-10 shows a rapid expansion which exceeds $1 \%$ length change after only 3 days of submerging in $1 \mathrm{~N} \mathrm{NaOH}$ solution. As a result, the samples cracked severely at an early age and length-change measurements were not practical at 7 days. The expansion observed in other geopolymer samples was much less than that observed with portland cement mortars. After 28 days of exposure, the expansion of GGF-0-10 and F-1-10 samples reached $0.04 \%$ and $0.06 \%$ respectively, while the expansion of portland cement mortars reached $0.84 \%$.

The dramatic expansion of GP-1-10 samples could be attributed to a number of factors, like the lesser amount of $\mathrm{Al}$ content in the matrix, the high amount of calcium content, and a large amount of readily available voids and cracks in the hardened matrix. Considering the results presented in Table 6, the amount of Al released in glass-powder geopolymers is very low, which results in low binding levels of alkalis in the geopolymer structure. Furthermore, presence of a high amount of calcium

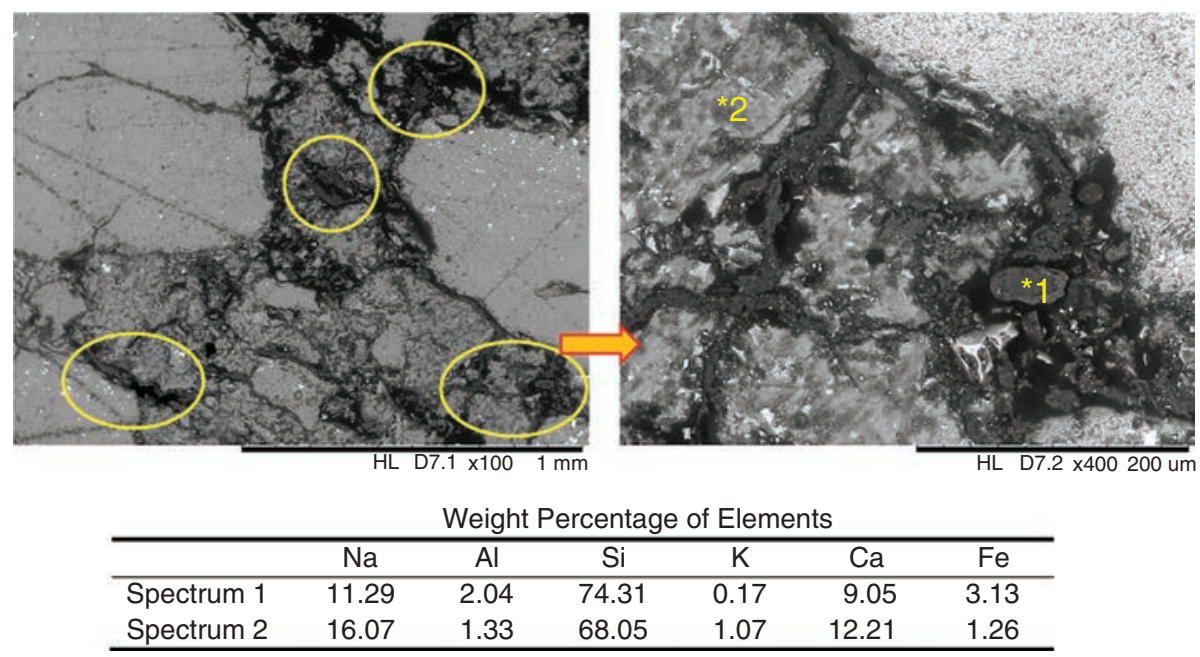

FIGURE 7. Formation of ASR gel in the paste matrix of GP-1-10 Paste.

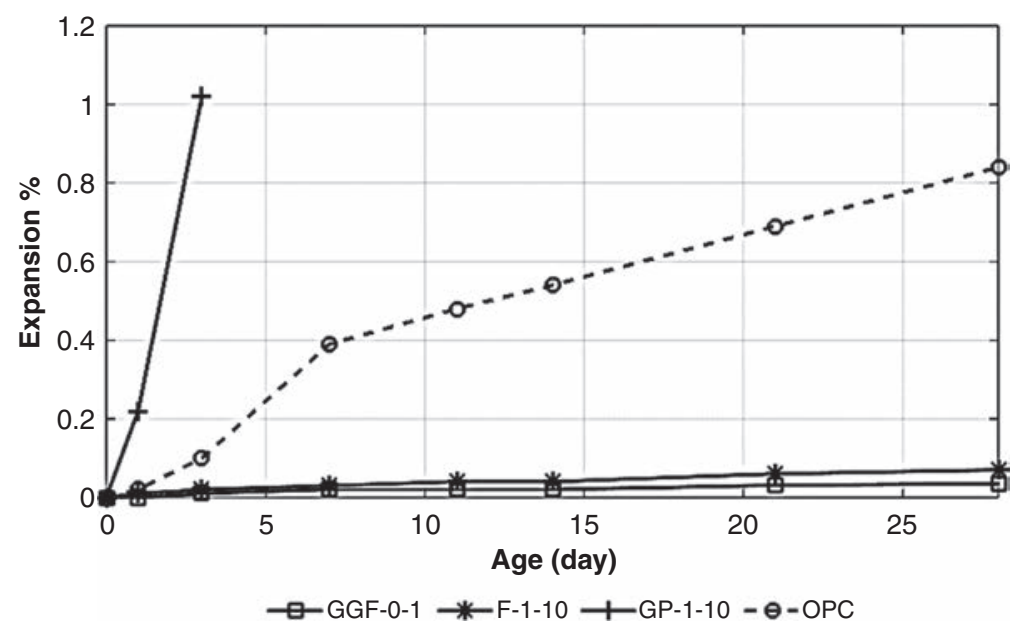

FIGURE 8. Expansion due to ASR. 
in the system leads to the formation of more rigid ASR gel, which causes more cracks and eases the attacking process in aggregates. In addition to these, as seen in Figure 8, as a result of the high amount of already available alkalis in the glasspowder geopolymers, ASR gel was observed in samples with non-reactive aggregate and no exposure to ASR accelerating conditions. Consequently, it is thought that ASR reaction contributing to such high expansion is taking place in the paste matrix of the glass-powder geopolymer itself rather than the aggregate surface. Although not presented in this paper, the SEM results of the samples made with reactive aggregates validated this assumption, as the aggregates were uncracked even in severely cracked mortar bars after 3 days of exposure to ASR accelerating conditions (Figure 9).

On the other hand, lower expansions of F-1-10 and GGF-1-10 samples are related to densification of the paste matrix in the presence of $\mathrm{NaOH}$ solution. Un-reacted material can go through the reaction process again forming stronger and more uniform paste, which limits the alkali attack on aggregates. Although availability of $\mathrm{Ca}$ in cementitious mixtures is known to be deleterious for ASR resistance; and the lower ASR-related expansion of fly ash-based geopolymers has been explained by this parameter $(33,35,37)$, GGF samples did

TABle 6. Extent of the Dissolution of GGF, Fly ash and Glass-Powder in a High Alkali Media (5N NaOH Solution, for $2 \mathrm{~h}$ )

\begin{tabular}{lccc}
\hline Sample & Ca (ppm) & Al (ppm) & Si (ppm) \\
\hline Fly ash & 315 & 141 & 748 \\
GGF & 696 & 142 & 1156 \\
Glass Powder & 816 & 28 & 724 \\
\hline
\end{tabular}

not follow this trend. The low expansion of GGFbased sample might be related to its very low porosity as well as low $\mathrm{Ca}(\mathrm{OH})_{2}$ content. Results of Mercury Intrusion Porosimetry (MIP) test on 3 -days old mortar samples showed a much lower total porosity of the GGF-0-10 mixture $\left(33 \mathrm{~mm}^{3} / \mathrm{g}\right)$ in comparison to F-1-10 $\left(100 \mathrm{~mm}^{3} / \mathrm{g}\right)$ and GP-1$10\left(74 \mathrm{~mm}^{3} / \mathrm{g}\right)$ mixtures. In addition, it should also be noted that not all the $\mathrm{Ca}$ content of the paste (i.e. already fixed $\mathrm{Ca}$ ) can participate in the formation of ASR gel, and therefore studies such as TGA might be useful to measure the amount of $\mathrm{Ca}(\mathrm{OH})_{2}$ in the GGF-based geopolymer paste. It is thought that the higher amount of $\mathrm{Ca}(\mathrm{OH})_{2}$ in the paste can increase the potential of the formation of a more rigid ASR gel, which will cause larger expansion. The TGA results showed a very low level of $\mathrm{Ca}(\mathrm{OH})_{2}$ in both fly ash-based $(0.7 \%$ of total weight) and GGF based geopolymer (1.1\% of total weight) paste samples (Figure 10).

SEM pictures taken from the GGF-0-10 sample and the F-1-10 sample after 14 days of exposure are presented in Figure 11. As presented, no significant signs of cracks can be seen in both samples. Interestingly, the paste matrix of GGF samples remained intact as unreacted GGF particles can clearly be seen in Figure 11-b. For the case of the F-1-10 sample, more reacted particles were seen in the paste matrix in comparison to the unexposed samples. This indicates the role of high alkali media in the secondary reaction of unreacted particles. The lower amount of alkali-silica reaction in both cases can be attributed to the stabilization of alkalis by unreacted material, the lower level of available calcium in form of $\mathrm{Ca}(\mathrm{OH})_{2}$, as well as the rigid structure of GGF-0-10 paste which reduces the permeability. It should also be noted that no visible ASR gel was observed around the aggregates.
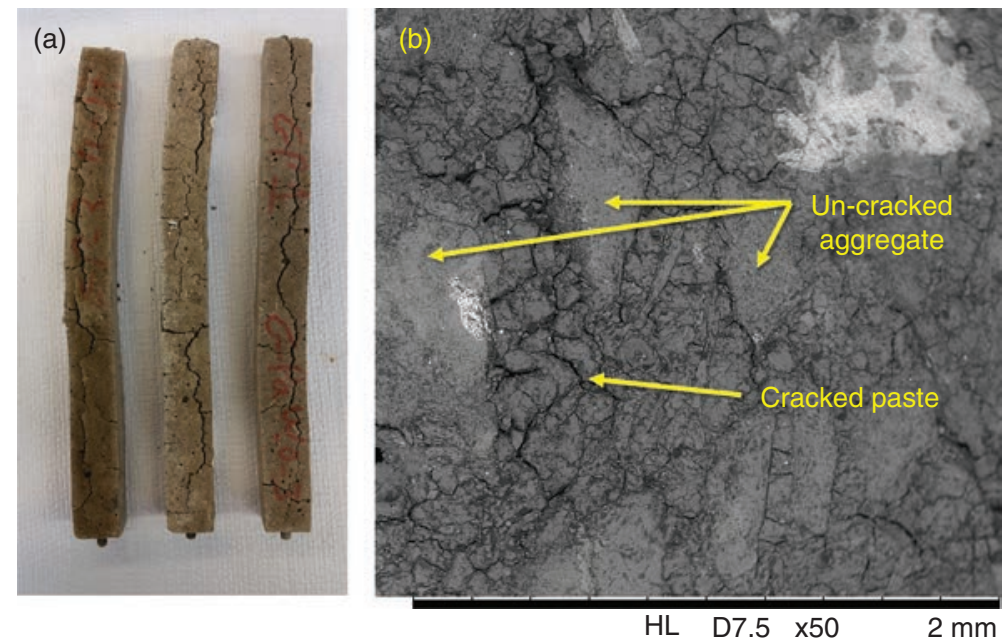

FIGURE 9. a) Severely cracked mortar bars after 7 days of exposure to ASR accelerating condition, and b) SEM picture of GLP-110 sample after 3 days of exposure to ASR accelerating condition. 

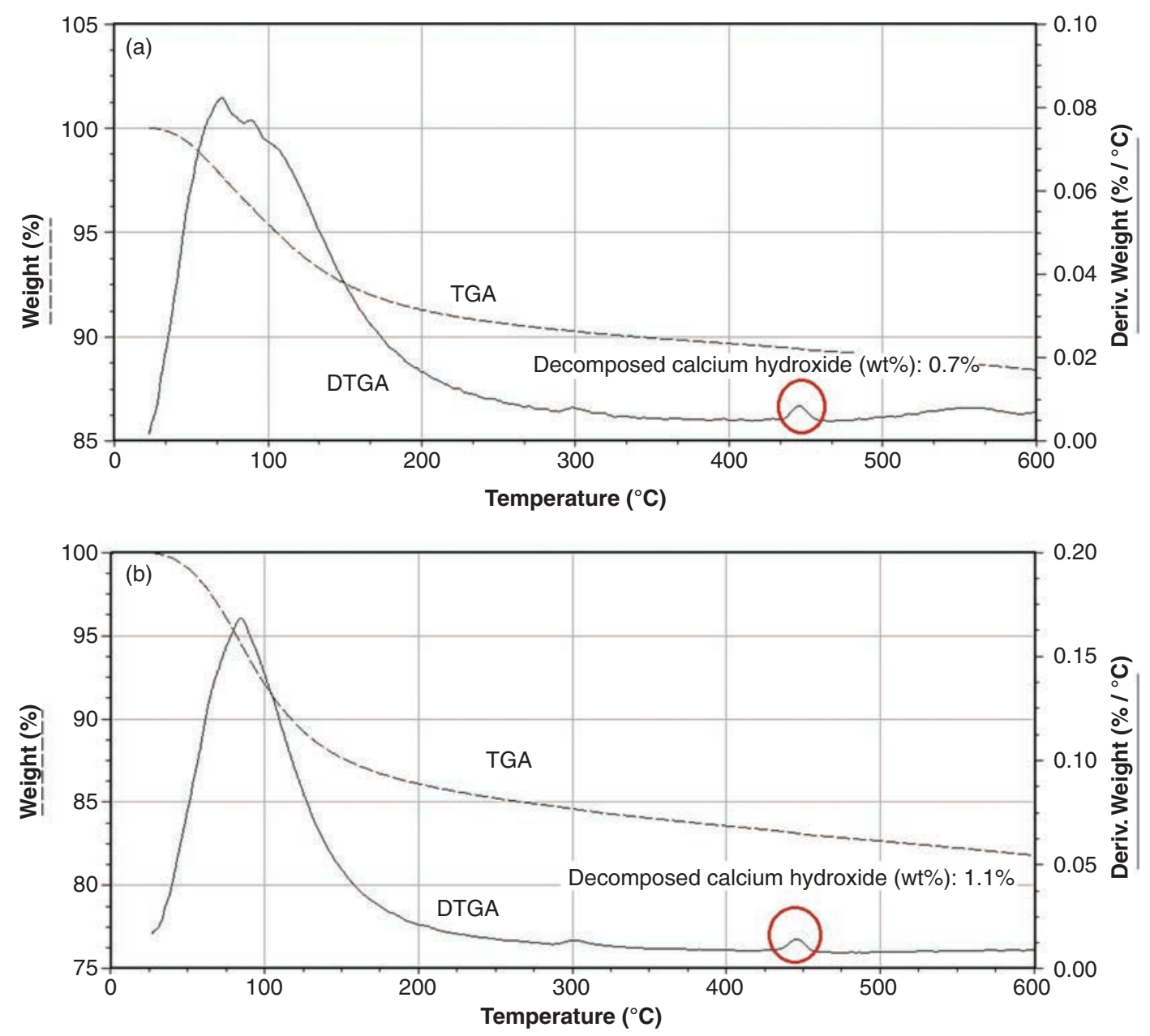

Figure 10. TGA and DTGA curve of 7-days old paste samples. a) F-1-10 paste, and b) G-0-10 paste.

\section{CONCLUSIONS}

Based on the findings from this investigation, the following conclusions were drawn:

1. Increase in the $\mathrm{Na}$ content of the activator solution did not seem to have a considerable effect on the workability of the GGF and fly ash-based mixtures, but caused improvement in the workability of glass-powderbased mixtures. On the other hand, increase in the soluble $\mathrm{Si}$ content, in terms of $\mathrm{SiO}_{2} /$ $\mathrm{Na}_{2} \mathrm{O}$ content caused improvement in the workability.

2. The role of $\mathrm{Na}$ content was observed to be significant in affecting the compressive strength of all the geopolymer mixtures investigated in this study. The 28-day compressive strength increased with an increase in $\mathrm{Na}$ levels in all mixtures.

3. While addition of soluble $\mathrm{Si}$ (i.e. increase in $\mathrm{SiO}_{2} / \mathrm{Na}_{2} \mathrm{O}$ ) to mixtures improved compressive strength of fly ash and glass-powder-based geopolymers, it reduced the compressive strength of GGF geopolymer samples. The highest compressive strength in GGF geopolymers was observed in samples with no added silica, i.e. $\mathrm{SiO}_{2} / \mathrm{Na}_{2} \mathrm{O}=0$. This is thought to be because of the higher degrees of geopolymerisation of GGF particles in the GGF-0-10 samples, with no addition of sodium silicate in the activator solution.

4. In terms of alkali-silica reaction, the glasspowder-based geopolymer showed a very poor resistance against ASR as mortar bars showed severe cracking and significant expansion. However, fly ash and GGF-based geopolymer mortar bars showed a much lower expansion in comparison to portland cement mortar specimens. Also, results from SEM analysis of polished specimens from GGF and fly ash mortar bars subjected to ASR tests showed a dense paste matrix with little cracking. 

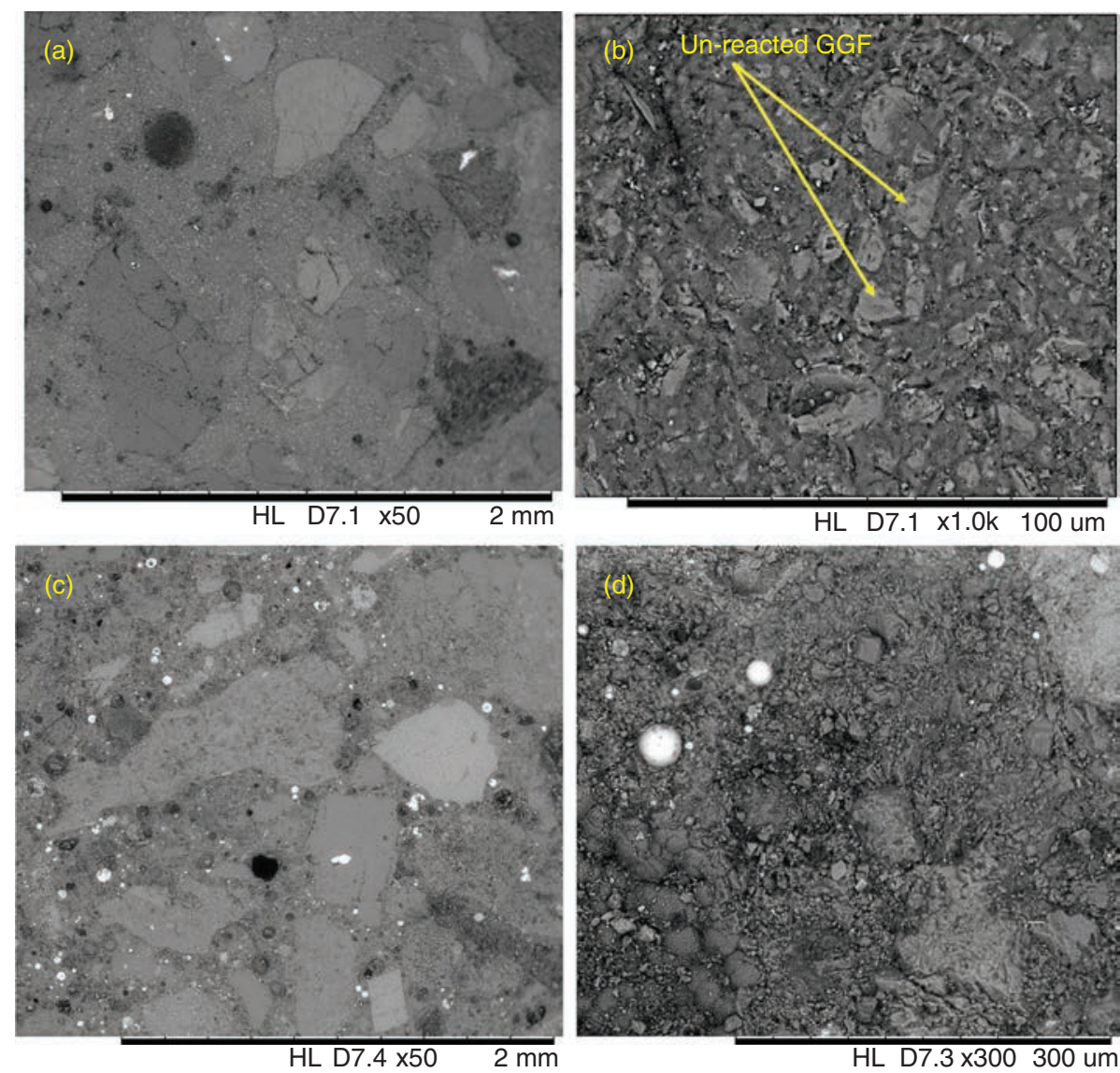

FIGURE 11. SEM of GGF-0-10, a) Uncracked aggregate, and b) paste matrix. SEM of F-1-10, c) Uncracked aggregate, and d) Paste Matrix.

\section{REFERENCES}

1. Hemmings, R. T. (2005) Process for Converting Waste Glass Fiber into Value Added Products, Final Report (No. DOE GO13015-1). Albacem LLC.

2. Chen, C. H.; Huang, R.; Wu J. K.; Yang, C. C. (2006) Waste E-glass particles used in cementitious mixtures. Cem. Concr. Res. 36 [3], 449-456. https://doi.org/10.1016/j. cemconres.2005.12.010

3. Hossain, A.; Shirazi, S.; Persun, J.; Neithalath, N. (2008) Properties of concrete containing vitreous calcium aluminosilicate pozzolan. J Transp. Res. Record. (2070), 32-38. https://doi.org/10.3141/2070-05.

4. Neithalath, N.; Persun, J.; Hossain, A. (2009) Hydration in high-performance cementitious systems containing vitreous calcium aluminosilicate or silica fume. Cem. Concr. Res. 39 [6], 473-481. https://doi.org/10.1016/j. cemconres.2009.03.006.

5. Tashima, M. M.; Soriano, L.; Borrachero, M. V.; Monzó, J.; Cheeseman C. R.; Payá, J. (2012) Alkali activation of vitreous calcium aluminosilicate derived from glass fiber waste. Journal of Sustainable Cement-Based Materials. 1 [3], 83-93. https://doi.org/10.1080/21650373.2012.742610.

6. Tashima, M. M.; Soriano, L.; Monzo, J.; Borrachero, M. V.; Paya, J. (2013) Novel geopolymeric material cured at room temperature. Adv. App. Ceram. 112 [4], 179-183. https://doi. org/10.1179/1743676112Y.0000000056.

7. Duxson, P.; Fernández-Jiménez, A.; Provis, J.L.; Lukey, G.C.; Palomo, A.; Van Deventer, J.S.J. (2007) Geopolymer technology: the current state of the art. $J$. Mater. Sci. 42 [9], 2917-2933. https://doi.org/10.1007/ s10853-006-0637-z.
8. Ganesan, N.; Abraham, R.; Raj, S.D.; Sasi, D.; (2014) Stress-strain behaviour of confined Geopolymer concrete. Constr. Build. Mater. 73, 326-331. https://doi. org/10.1016/j.conbuildmat.2014.09.092.

9. Morsy, M.S.; Alsayed, S.H.; Al-Salloum, Y.; Almusallam, T. (2014) Effect of sodium silicate to sodium hydroxide ratios on strength and microstructure of fly ash geopolymer binder. Arab. J Sci. Eng. 39 [6], 4333-4339. https://doi. org/10.1007/s13369-014-1093-8.

10. Van Jaarsveld, J.G.S.; Van Deventer, J.S.J; Lukey, G.C (2003) The characterization of source materials in fly ashbased geopolymers. Mater. Lett. 57 [7], 1272-1280. https:// doi.org/10.1016/S0167-577X(02)00971-0

11. Ryu, G.S.; Lee, Y.B.; Koh, K.T; Chung, Y.S. (2013) The mechanical properties of fly ash-based geopolymer concrete with alkaline activators. Constr. Build. Mater. 47, 409418. https://doi.org/10.1016/j.conbuildmat.2013.05.069.

12. Li, C.; Sun, H.; Li, L. (2010) A review: The comparison between alkali-activated slag ( $\mathrm{Si}+\mathrm{Ca}$ ) and metakaolin (Si+Al) cements. Cem. Concr. Res. 40 [9], 1341-1349. https://doi.org/10.1016/j.cemconres.2010.03.020.

13. Kumar, S.; Kumar, R.; Mehrotra, S.P.; (2010) Influence of granulated blast furnace slag on the reaction, structure and properties of fly ash based geopolymer. J. Mater. Sci. 45 [3], 607-615. https://doi.org/10.1007/s10853-009-3934-5.

14. Oh, J.E.; Monteiro, P.J.; Jun, S.S.; Choi, S; Clark, S.M. (2010) The evolution of strength and crystalline phases for alkali-activated ground blast furnace slag and fly ash-based geopolymers. Cem. Concr. Res. 40 [2], 189-196. https://doi. org/10.1016/j.cemconres.2009.10.010.

15. Xu, H.; Van Deventer, J.S. (2002) Geopolymerisation of multiple minerals. Miner. Eng. 15 [12], 1131-1139. https:// doi.org/10.1016/S0892-6875(02)00255-8. 
16. Anuar, K.A.; Ridzuan, A.R.M.; Ismail, S. (2011) Strength characteristic of geopolymer concrete containing recycled concrete aggregate. International Journal of Civil \& Environmental Engineering IJCEE-IJENS. 11 [1], http:// ijens.org/Vol\%2011\%20I\%2001/119601-2323\%20IJCEEIJENS.pdf

17. Bhutta, M.A.R.; Hussin, W.M.; Azreen, M; Tahir, M.M. (2014) Sulphate resistance of geopolymer concrete prepared from blended waste fuel ash. J Mater Civil Eng. 26. https://doi.org/10.1061/(ASCE)MT.1943-5533.0001030.

18. Trochez, J. J.; Mejía de Gutiérrez, R.; Rivera, J.; Bernal, S. A. (2015). Synthesis of geopolymer from spent FCC: Effect of $\mathrm{SiO}_{2} / \mathrm{Al}_{2} \mathrm{O}_{3}$ and $\mathrm{Na}_{2} \mathrm{O} / \mathrm{SiO}_{2}$ molar ratios. Mater. Construcc. 65 [317]. https://doi.org/10.3989/mc.2015.00814

19. Pascual, A. B.; Tognonvi, M. T.; Tagnit-Hamou, A. (2014). Waste glass powder-based alkali-activated mortar. In NTCC2014: International Conference on Non-Traditional Cement and Concrete.

20. Sukmak, P.; Horpibulsuk, S.; Shen, S.L. (2013) Strength development in clay-fly ash geopolymer. Constr. Build. Mater. 40, 566-574. https://doi.org/10.1016/j.conbuildmat.2012.11.015.

21. Nazari, A.; Maghsoudpour, A. and Sanjayan, J.G. (2014) Characteristics of boroaluminosilicate geopolymers. Constr. Build. Mater. 70, 262-268. https://doi. org/10.1016/j.conbuildmat.2014.07.087.

22. Robayo, R. A.; Mejía de Gutiérrez, R.; Gordillo, M. (2016) Natural pozzolan-and granulated blast furnace slag-based binary geopolymers. Mater. Construcc. 66 [321], https://doi. org/10.3989/mc.2016.03615.

23. Wang, H.; Li, H.; Yan, F. (2005) Synthesis and mechanical properties of metakaolinite-based geopolymer. Colloids and Surfaces A: Physicochemical and Engineering Aspects, 268 [1], 1-6. https://doi.org/10.1016/j.colsurfa. 2005.01.016.

24. Hardjito, D.; Wallah, S.E.; Sumajouw, D.M; Rangan, B.V. (2004). On the development of fly ash-based geopolymer concrete. ACI materials journal, 101 [6]

25. Phair, J.W.; and Van Deventer, J.S.J. (2002) Effect of the silicate activator $\mathrm{pH}$ on the microstructural characteristics of waste-based geopolymers. Int. J Miner. Process. 66 [1]. https://doi.org/10.1016/S0301-7516(02)00013-3.

26. Palomo, A.; Grutzeck, M.W.; Blanco, M.T. (1999) Alkali-activated fly ashes: a cement for the future. Cem. Concr. Res. 29 [8], 1323-1329. https://doi.org/10.1016/ S0008-8846(98)00243-9.

27. Buchwald, A.; Dombrowski, K; Weil, M. (2005) The influence of calcium content on the performance of geopolymeric binder especially the resistance against acids. Proceedings of the world geopolymer. St. Quentin, France (2005).

28. Lee, W. K. W.; Van Deventer, J. S. J. (2002) The effect of ionic contaminants on the early-age properties of alkaliactivated fly ash-based cements. Cem. Concr. Res. 32 [4], 577-584. https://doi.org/10.1016/S0008-8846(01)00724-4

29. Xu, H.; Van Deventer, J. S. J. (2000) The geopolymerisation of alumino-silicate minerals. Int. J Miner. Process. 59 [3], 247-266. https://doi.org/10.1016/S0301-7516(99)00074-5.

30. De Silva, P.; Sagoe-Crenstil, K.; Sirivivatnanon, V. (2007) Kinetics of geopolymerization: role of $\mathrm{Al} 2 \mathrm{O} 3$ and $\mathrm{SiO} 2$. Cem. Concr. Res. 37 [4], 512-518. https://doi.org/10.1016/j. cemconres.2007.01.003

31. Kouamo, H. T.; Elimbi, A.; Mbey, J. A.; Sabouang, C. N.; Njopwouo, D. (2012) The effect of adding alumina-oxide to metakaolin and volcanic ash on geopolymer products: A comparative study. Constr. Build. Mater. 35, 960-969. https:/doi.org/10.1016/j.conbuildmat 2012.04.023.

32. Duxson, P.; Provis, J. L.; Lukey, G. C.; Mallicoat, S. W.; Kriven, W. M.; Van Deventer, J. S. (2005). Understanding the relationship between geopolymer composition, microstructure and mechanical properties. Colloids and Surfaces A: Physicochemical and Engineering Aspects, 269 [1], 47-58. https://doi.org/10.1016/j.colsurfa.2005.06.060.

33. Kupwade-Patil, K.; Allouche, E.N. (2013) Impact of Alkali Silica Reaction on Fly Ash-Based Geopolymer Concrete. J Mater Civil Eng. 25 [1], 131-139. https://doi.org/10.1061/ (ASCE)MT 1943-5533.0000579.

34. Puertas, F.; Palacios, M.; Gil-Maroto; A. and Vázquez, T. (2009) Alkali-aggregate behaviour of alkali-activated slag mortars: Effect of aggregate type. Cem. Concr. Comp. 31 [5], 277-284. https://doi.org/10.1016/j.cemconcomp.2009.02.008.

35. Fernández-Jiménez, A.; Garcia-Lodeiro, I.; Palomo, A. (2007) Durability of alkali-activated fly ash cementitious materials. J. Mater. Sci. 42(9), 3055-3065. http://doi. org/10.1007/s10853-006-0584-8.

36. Xie, Z.; Xiang, W.; Xi, Y. (2003) ASR potentials of glass aggregates in water-glass activated fly ash and portland cement mortars. J Mater Civil Eng. 15 [1], 67-74. http://doi. org/10.1061/(ASCE)0899-1561(2003)15:1(67).

37. Pouhet, R.; Cyr, M. (2015) Alkali-silica reaction in metakaolin-based geopolymer mortar. Mater Struct, 48 [3], 571-583. https://doi.org/10.1617/s11527-014-0445-x.

38. ASTM International: Standard Specification for Portland cement (ASTM C150) (2016). https://doi.org/10.1520/ C0150 C0150M-16.

39. ASTM International: Standard Test Method for Flow of Hydraulic Cement Mortar (ASTM C1437) (2013). https:// doi.org/10.1520/C1437-13

40. ASTM International: Standard Test Method for Compressive Strength of Hydraulic Cement Mortars (Using 2-in. or [50-mm] Cube Specimens) (ASTM C109) (2013). https://doi.org/10.1520/C0109 C0109M-13.

41. Struble, L; Hicks, J. K. (2013) Geopolymer Binder Systems, ASTM International. New York, (2013).

42. Palomo, A.; Alonso, S., Fernandez-Jiménez, A.; Sobrados, I.: Sanz, J. (2004) Alkaline activation of fly ashes: NMR study of the reaction products. J Am. Ceram. Soc. 87 [6], 11411145. https://doi.org/10.1111/j.1551-2916.2004.01141.x.

43. ASTM International: Standard Test Method for Potential Alkali Reactivity of Aggregates (Mortar-Bar Method) (ASTM C1260) (2014). https://doi.org/10.1520/ C1260-14.

44. Sathonsaowaphak, A.; Chindaprasirt, P.; Pimraksa, K. (2009) Workability and strength of lignite bottom ash geopolymer mortar. J Hazard. Mater. 168 [1], 44-50. https:// doi.org/10.1016/j.jhazmat.2009.01.120.

45. Malkawi, A. B.; Nuruddin, M. F.; Fauzi, A.; Almattarneh, H.; Mohammed, B. S. (2016) Effects of Alkaline Solution on Properties of the HCFA Geopolymer Mortars. Procedia Engineering. 148, 710-717. https://doi.org/10.1016/j. proeng.2016.06.581.

46. Chindaprasirt, P.; Chareerat, T.; Sirivivatnanon, V. (2007) Workability and strength of coarse high calcium fly ash geopolymer. Cem. Concr. Comp. 29 [3], 224-229. https://doi. org/10.1016/j.cemconcomp.2006.11.002.

47. Bhowmick, A.; Ghosh, S. (2012) Effect of synthesizing parameters on workability and compressive strength of fly ash based geopolymer mortar. International journal of civil and structural engineering, 3 [1], http://www.ipublishing.co.in/ ijcserarticles/twelve/lpages/0301/jcserlpvol3issue100016. html.

48. Yip, C.K.; Lukey, G.C.; Van Deventer, J.S.J. (2005) The coexistence of geopolymeric gel and calcium silicate hydrate at the early stage of alkaline activation. Cem. Concr. Res. 35 [9], 1688-1697. https://doi.org/10.1016/j. cemconres.2004.10.042.

49. Yao, Z.; Ye, Y.; Xia, M. (2013) Synthesis and characterization of lithium zeolites with ABW type from coal fly ash. Environmental Progress \& Sustainable Energy. 32 [3], 790-796. https://doi.org/10.1002/ep.11689.

50. Fernández-Jiménez, A.; Palomo, A.; Sobrados, I.; Sanz, J. (2006) The role played by the reactive alumina content in the alkaline activation of fly ashes. Micropor. Mesopor. Mat. 91 [1], 111-119. https://doi.org/10.1016/j. micromeso.2005.11.015.

51. Temuujin, J.; Van Riessen, A. (2009) Effect of fly ash preliminary calcination on the properties of geopolymer. $J$ Hazard. Mater. 164 [2], 634-639. https://doi.org/10.1016/j. jhazmat.2008.08.065.

52. Glasser, L.S.D.; Harvey, G. (1984) The unexpected behaviour of potassium aluminosilicate solutions. Journal of the Chemical Society, Chem. Commun. 10, 664-665. https://doi. org/10.1039/c39840000664.

53. Davidovits, J. (1999) Chemistry of geopolymeric systems, terminology. In: Proceedings of 99 International Conference. France. 9-40. 